\title{
Microbial and nutrient dynamics in mangrove, reef, and seagrass waters over tidal and diurnal time scales
}

\author{
Cynthia C. Becker ${ }^{1,2}$, Laura Weber ${ }^{1}$, Justin J. Suca ${ }^{1,2}$, Joel K. Llopiz ${ }^{1}$, \\ T. Aran Mooney ${ }^{1}$, Amy Apprill ${ }^{1, *}$ \\ ${ }^{1}$ Woods Hole Oceanographic Institution, 266 Woods Hole Rd, Woods Hole, MA 02543, USA \\ ${ }^{2}$ MIT-WHOI Joint Program in Oceanography/Applied Ocean Science \& Engineering, Cambridge 02139, \\ and Woods Hole 02543, MA, USA
}

\begin{abstract}
In coral reefs and adjacent seagrass meadow and mangrove environments, short temporal scales (i.e. tidal, diurnal) may have important influences on ecosystem processes and community structure, but these scales are rarely investigated. This study examines how tidal and diurnal forcings influence pelagic microorganisms and nutrient dynamics in 3 important and adjacent coastal biomes: mangroves, coral reefs, and seagrass meadows. We sampled for microbial (Bacteria and Archaea) community composition, cell abundances and environmental parameters at 9 coastal sites on St. John, US Virgin Islands that spanned $4 \mathrm{~km}$ in distance (4 coral reefs, 2 seagrass meadows and 3 mangrove locations within 2 larger bays). Eight samplings occurred over a $48 \mathrm{~h}$ period, capturing day and night microbial dynamics over 2 tidal cycles. The seagrass and reef biomes exhibited relatively consistent environmental conditions and microbial community structure but were dominated by shifts in picocyanobacterial abundances that were most likely attributed to diel dynamics. In contrast, mangrove ecosystems exhibited substantial daily shifts in environmental parameters, heterotrophic cell abundances and microbial community structure that were consistent with the tidal cycle. Differential abundance analysis of mangrove-associated microorganisms revealed enrichment of pelagic oligotrophic taxa during high tide and enrichment of putative sediment-associated microbes during low tide. Our study underpins the importance of tidal and diurnal time scales in structuring coastal microbial and nutrient dynamics, with diel and tidal cycles contributing to a highly dynamic microbial environment in mangroves, and time of day likely contributing to microbial dynamics in seagrass and reef biomes.
\end{abstract}

KEY WORDS: Tide $\cdot$ Picoplankton $\cdot$ Mangrove $\cdot$ Coral reef $\cdot$ Seagrass $\cdot$ Time series $\cdot 16$ S rRNA gene

\section{INTRODUCTION}

Short temporal rhythmicities resulting from daily sunlight cycles and lunar-influenced tidal cycles have governed the dynamics of living organisms throughout evolutionary history. Light is a fundamental source of energy for the photosynthetic cells that dominate in the surface ocean worldwide and produce approximately $46 \%$ of global net primary production (Field et al. 1998). Tidal elevation directs

${ }^{*}$ Corresponding author: aapprill@whoi.edu the zonation of intertidal flora and fauna along coastlines, influencing local community processes (Alongi 1987, Peterson 1991). Coastal ecosystems must cope with the interaction of both diurnal and tidal forcings, and the effects of these cycles are apparent on microbial scales. The tidal cycle influences virus-microbe interactions in estuaries (Chen et al. 2019), bacterial abundances in salt marshes (Kirchman et al. 1984), and even the presence of enterococci, fecal bacteria used as a metric for water quality, on beaches (Boehm

() The authors 2020. Open Access under Creative Commons by Attribution Licence. Use, distribution and reproduction are unrestricted. Authors and original publication must be credited. 
\& Weisberg 2005). Diurnal cycles, on the other hand, govern microbial nitrogen fixation on mangrove root systems (Toledo et al. 1995), bacterial production rates in seagrass meadows (Moriarty \& Pollard 1982), and coral reef microbial community changes (Kelly et al. 2019, Weber \& Apprill 2020). Together, tidal and diurnal forces play major roles in shaping microbial life in coastal environments.

Seawater bacterial and archaeal communities are fundamental to ocean ecosystems. These prokaryotic microbes form the basis of the marine food web because they cycle organic matter, remineralize nutrients, and take part in all major elemental cycles in the ocean (reviewed by Moran 2015). Extensive study of microbial communities in the ocean has primarily focused on seasonal changes and shown that communities vary predictably with environmental factors, such as temperature (Fuhrman et al. 2006, Gilbert et al. 2009, Kim \& Ducklow 2016, Bunse \& Pinhassi 2017). The dynamics of microbial communities over short temporal scales (hours to days) are less studied. Studies from estuarine and coastal environments showed that tidal mixing and salinity are major drivers of microbial community structure (Lu et al. 2015, Chen et al. 2019, Neubauer et al. 2019). In the case of open ocean environments with more stable physical and chemical features, observed changes in microbial communities may be due to biological interactions. For example, a study centered off the coast of California over 3 wk and following a spring bloom showed that the microbial community composition correlated more closely to biological variables than physical and chemical variables (Needham \& Fuhrman 2016). Short-term microbial dynamics likely play a role in structuring seawater microbial communities within coastal tropical marine environments (mangrove, seagrass and coral reef), but these dynamics are largely unstudied.

Mangrove, seagrass, and coral reef biomes dominate the coast of many tropical and subtropical islands and coastlines. Together, these ecosystems protect coastlines from devastating tropical storms and hurricanes, and they sustain local economies that rely on tourism and seafood. Mangroves are halophytic plants that thrive in the transition zone between estuarine and marine environments, tolerating a wide range of physicochemical conditions. Collectively, these trees make up mangrove forests, which are critically important coastal biomes. They sequester carbon (Donato et al. 2011), provide nursery grounds for fish (Aburto-Oropeza et al. 2008), and insulate coastlines from storms and erosion (Duke et al. 2007). At the micro-scale, mangrove ecosystems are impor- tant for remineralization as they harbor microorganisms in sediments, roots, and seawater that include denitrifying and nitrogen-fixing bacteria (Reef et al. 2010, Liu et al. 2012). Mangrove sediment microbial community dynamics are well studied and have been shown to respond to tidal changes, which affect ecosystem processes such as rates of nitrogen fixation and denitrification (Lee \& Joye 2006, Chen et al. 2016, Gong et al. 2019). Given the influence of tide on sediment microbial communities, there may be a concomitant shift in the overlying seawater microbial communities with respect to the tidal forcing of seawater. However, the extent of tidal influence on the microbial dynamics within the overlying seawater remains to be elucidated in mangrove environments.

Seagrass meadows are often found deeper than mangroves, where they are constantly submerged, yet within the photic zone. These environments serve as nursery grounds and habitat for diverse fishes and invertebrates, and they contribute significantly to primary production in tropical ecosystems (reviewed in Ugarelli et al. 2017). Sediment-associated microbial communities in seagrasses are important for nitrogen cycling and carbon sequestration (Moriarty et al. 1985, Sun et al. 2015, Ugarelli et al. 2018). The seawater microbial community is far less studied but has been shown to be important for carbon cycling and the ultimate transfer of primary production to the marine food web (Blum \& Mills 1991, Peduzzi \& Herndl 1991). Ugarelli et al. (2018) recently examined the spatial variability in seawater microorganisms across 3 seagrass locations and found quite consistent patterns in the taxa recovered across sites, but small changes in relative abundances of those taxa. Short temporal scales do appear to exert an effect on the microbial communities in seagrass environments. The bacterial production rates within sediment and seawater in seagrass meadows have been shown to change on a diurnal cycle in response to the photosynthetic output of the underlying plants, but this did not relate to the tidal cycle, according to Moriarty \& Pollard (1982). The extent that the composition of overlying seawater bacterial and archaeal communities changes over similar short temporal cycles remains to be described.

High biodiversity from macro- to micro-organisms and low nutrient concentrations of overlying seawater are hallmarks of coral reef environments. The diverse assemblage of microorganisms is particularly important in reef seawater for recycling organic metabolites and nutrients in these apparent nutrient 'deserts' (Gast et al. 1998, Bourne \& Webster 2013, Haas et al. 2013). The fundamental role that microbes 
play in coral reef biogeochemical cycling has made them bioindicators of changing reef environments in the face of climate change (Glasl et al. 2018). While it is established that seawater microbial communities on reefs alter predictably with seasonal shifts in environmental parameters (Bulan et al. 2018, Glasl et al. 2019), much less is known on how short temporal scales, on the orders of hours and days, impact reef seawater communities. Existing studies suggest that seasonal and diurnal changes could be more significant than tidal changes in reef systems (Sweet et al. 2010, Kelly et al. 2019, Weber \& Apprill 2020). While diurnal changes may be more significant than tidal changes in reef ecosystems, at present no data exist in the Caribbean on the effect of tidal changes on reef and other coastal marine seawater microbial communities, precluding a complete assessment of major temporal drivers in reef and other coastal tropical systems.

The objectives of our study were to (1) provide an initial understanding of the variability in the physicochemical environment over 2 tidal and diurnal cycles at 3 tropical biomes simultaneously in St. John, US Virgin Islands (USVI), (2) capture the changes in microbial communities at those same locations and time points, and (3) examine the influence of tidal level and time of day on structuring bacterial and archaeal community composition in these environments. We sampled the seawater at 9 sites on the southern shore of St. John, USVI, over 2 full spring tidal cycles in July 2017, which extended over $48 \mathrm{~h}$ and included day and night measurements. Much of this study took place in the Virgin Islands National Park, which extends from land into the surrounding waters, protecting mangrove, seagrass, and reef biomes in close proximity to each other. We hypothesized that the mangrove habitats, which reside closest to the intertidal zone, would experience a physicochemical environment that varied in concert with the tide, leading to a more dynamic microbial community compared to reef and seagrass biomes. We hypothesized that any tidal-based changes in the reef and seagrass biomes would be subtler compared to the mangroves and that these environments would show some evidence of diurnal-based microbial community alterations.

\section{MATERIALS AND METHODS}

\subsection{Sampling}

The study took place on the southern coast of St. John, USVI, in 2 comparable bays, Lameshur Bay and Fish Bay, during summer of 2017 (prior to hurricanes Irma and Maria). In total, 3 tropical biomes were sampled: coral reef (4 sites), seagrass meadow (2 sites) and mangrove ( 3 sites; 2 within the same mangrove system) (Fig. 1). The Lameshur Bay mangrove location included 2 distinct sampling sites. The 'Lameshur mangrove inland' area was at the upper range of the intertidal zone and was dominated by black mangroves Avicennia germinans and white mangroves Laguncularia racemosa. The Lameshur mangrove inland environment was only flooded and sampled during high tide (Fig. 1). The second Lameshur Bay mangrove area was named 'Lameshur mangrove subtidal' because it was located below the mean low low water level. This habitat was dominated by red mangroves Rhizophora mangle, and its subtidal location caused it to be constantly submerged and enabled sampling at each time point (Fig. 1). The Fish Bay mangrove site was also a subtidal mangrove habitat surrounded by red mangroves that were sampled throughout the study. The seagrass meadows were dominated by turtle grass Thallassia testudinum but also included manatee grass Syringodium filliforme and shoal grass Halodule wrightii. The majority of sites were within the boundaries of the Virgin Islands National Park, which is undeveloped except for a small research station. The Fish Bay mangrove, Fish Bay seagrass, and Ditliff reef sites were outside the boundary of the park, and the land surrounding Fish Bay was inhabited.

Sampling occurred from July 22-24, 2017 and coincided with the spring tides and natural diel cycles. A new moon occurred on July 23 at 05:45 (EST). St. John tidal cycles exhibit a combination of mixed semidiurnal tides, which occur typically during neap tides, and diurnal tides, which occur around the spring tides (Fig. 1b). Sampling time points coincided with the diurnal tidal cycle at low, flood, high, and ebb tides over a $48 \mathrm{~h}$ window, resulting in 8 total sampling time points (gray dots, Fig. 1b). Due to the nature of the diurnal tide, over the $48 \mathrm{~h}$, low and flood tide only occurred during the day to dusk time period, while high and ebb tide only occurred during night and dawn, respectively. Samples were collected $\pm 1 \mathrm{~h}$ from the designated time point, placed on ice, and processed within $2 \mathrm{~h}$ of collection.

At all sites, a CTD (Castaway, SonTek) was deployed from surface to the bottom depths in reef and seagrass seawater, and single point measurements were collected from mangrove seawater to capture the temperature and salinity at each time point. Only temperature and salinity at the surface of the cast 

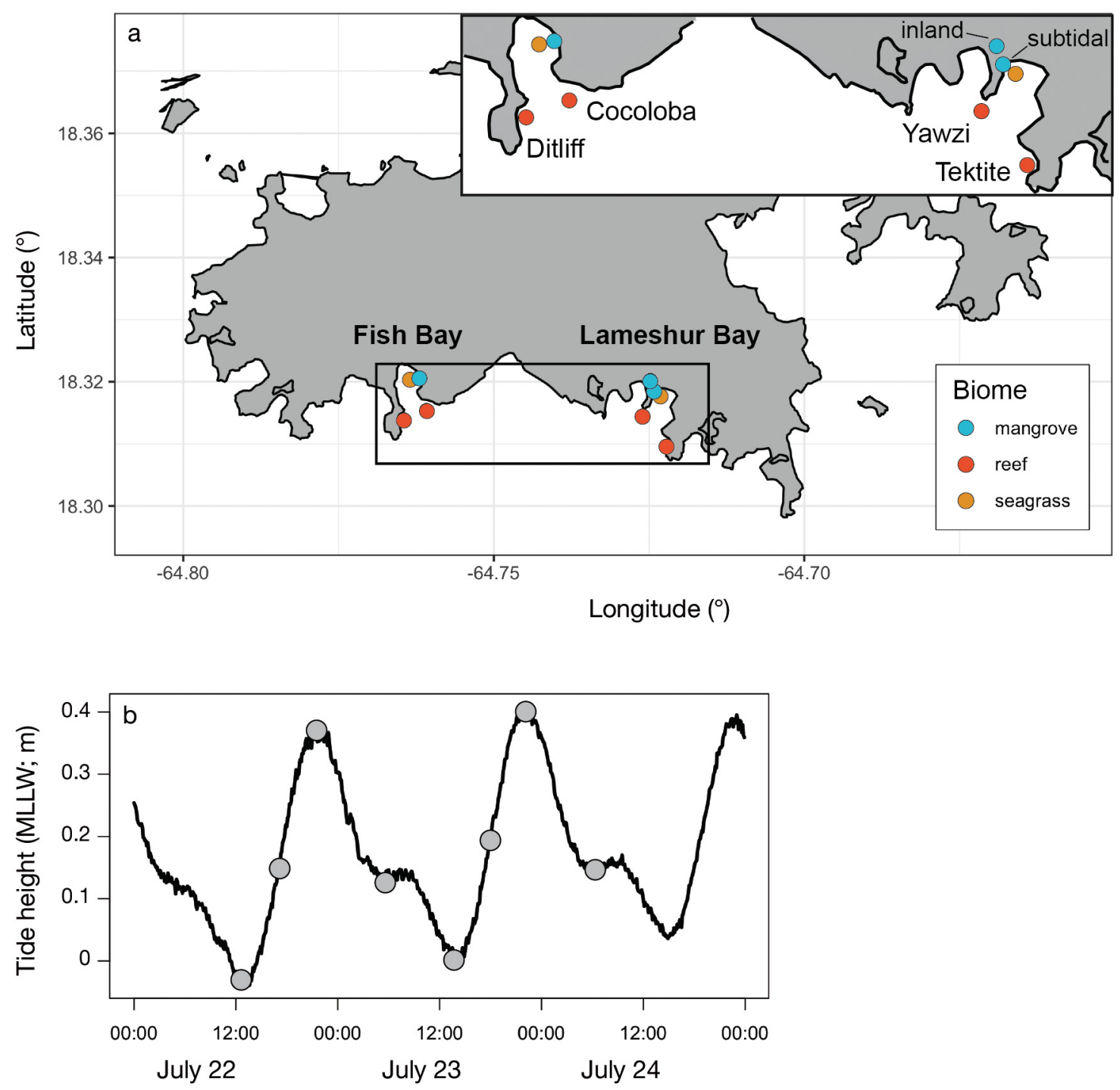

Fig. 1. Sampling area and tide height over the course of the sampling period. (a) Map of St. John, United States Virgin Islands (USVI) depicts mangrove (blue dots), reef (red dots), and seagrass (orange dots) sites in Fish Bay and Lameshur Bay with inset provided for greater detail in orientation of sampling locations. Reef sites are labeled by name (Ditliff, Cocoloba, Yawzi, Tektite). (b) Tide height relative to mean low low water (MLLW, m) plotted as a function of time with sampling time points indicated with gray dots. Tide height data were collected from NOAA/NOS/CO-OPS Station ID 9751381 in Lameshur Bay, St. John, USVI

were used for analysis. Water samples were collected from the surface (within $0.5 \mathrm{~m}$ ) after triplicate rinsing of each respective container. Water for inorganic nutrients $(30 \mathrm{ml})$ was transferred into acid-washed and seawater-rinsed bottles (HDPE, Nalgene, ThermoFisher Scientific), which were frozen to $-20^{\circ} \mathrm{C}$. Samples for microbial abundances $(875 \mu \mathrm{l})$ were transferred from nutrient bottles to a $2 \mathrm{ml}$ cryovial (Corning), which was fixed to a final concentration of $1 \%$ paraformaldehyde (Electron Microscopy Sciences), refrigerated in the dark for $20 \mathrm{~min}$ at $4^{\circ} \mathrm{C}$, then flash-frozen in a liquid nitrogen $\left(\mathrm{LN}_{2}\right)$ dry shipper. Samples were collected for total organic carbon and nitrogen but were contaminated during sample storage due to improper orientation of the cap seals, unfortunately preventing the incorporation of organic substrates in this study. To capture seawater microbial communities, water was collected into acid-washed, 41 Nalgene bottles (LDPE plastic, ThermoFisher Scientific) and $1 \mathrm{l}$ of seawater was pumped using a Masterflex L/S peristaltic pump (Cole-Palmer) through Masterflex silicone tubing (L/S, platinum-cured, \#96410-24 size, Cole-Parmer) to rinse the tubing. The remaining 21 of seawater was filtered through a $0.22 \mu \mathrm{m}$ Supor filter 
(25 mm; Pall). For the mangrove and seagrass sites, 21 could not always be filtered completely, and therefore 0.3-2 1 and 1.2-2 1 of water was filtered through the membrane, respectively. For the coral reef sites, 1.5-2 1 passed through the filter membrane. All filters were placed into $2 \mathrm{ml}$ cryovials using sterile forceps (Corning) and flash-frozen in an $\mathrm{LN}_{2}$ dry shipper until returned to Woods Hole, MA, and stored at $-80^{\circ} \mathrm{C}$.

\subsection{Flow cytometry and nutrient analyses}

Samples collected for microbial abundance were analyzed at the University of Hawaii SOEST Flow Cytometry Facility with a Beckman-Coulter Altra flow cytometer (Beckman Coulter Life Sciences) that was attached to a Harvard Apparatus syringe pump for quantitative sample delivery $\left(50 \mu \mathrm{min}^{-1}\right)$. Samples were stained with Hoechst 33342 DNA stain $\left(1 \mu \mathrm{g} \mathrm{ml}^{-1}\right.$ final concentration) and excited co-linearly by $488 \mathrm{~nm}(1 \mathrm{~W})$ and UV ( 350 nm, $200 \mathrm{~mW})$ lasers (Campbell \& Vaulot 1993, Monger \& Landry 1993). Signals were collected as FCS 2.0 listmode files using Expo32 software for scatter (forward and side) and fluorescence (chlorophyll, phycoerythrin and Hoechstbound DNA). Data were analyzed offline using FlowJo software (Tree Star). Populations and abundances (cells ml ${ }^{-1}$ ) of cyanobacteria (Prochlorococcus and Synechoccocus), eukaryotic phytoplankton and non-pigmented bacteria were distinguished based on their characteristic scatter, chlorophyll, phycoerythrin, and DNA signals. Non-pigmented bacteria were used as a proxy for heterotrophic Bacteria and Archaea (Monger \& Landry 1993, Marie et al. 1997).

Samples collected for nutrient analysis were analyzed at Oregon State University using a Technicon AutoAnalyzer II (SEAL Analytical) and an Alpkem RFA 300 Rapid Flow Analyzer. Ammonium was measured with the indophenol blue method (US Environmental Protection Agency 1983). Phosphate was measured with an adjusted molybdenum blue method (Bernhardt \& Wilhelms 1967), and nitrite + nitrate and silicate were measured using standard methods in Armstrong et al. (1967).

\subsection{DNA extraction, PCR amplification, and sequencing}

DNA was extracted from the $0.22 \mu \mathrm{m}$ filters using a sucrose-EDTA lysis method similar to Santoro et al. (2010) that combines lysis with filter column purification. Three DNA extraction controls were included with the following DNA extraction procedure on unused $0.22 \mu \mathrm{m}$ filters identical to those used for sample collection. Briefly, the $25 \mathrm{~mm}$ filter was subjected to physical and chemical lysis using $0.1 \mathrm{~mm}$ glass beads (Lysing Matrix B, MP Biomedicals), sucrose-EDTA lysis buffer $(0.75 \mathrm{M}$ Sucrose, $20 \mathrm{mM}$ EDTA, $400 \mathrm{mM} \mathrm{NaCl}, 50 \mathrm{mM}$ Tris) and $10 \%$ sodium dodecyl sulfate (Teknova), followed by a Proteinase $\mathrm{K}$ digestion $\left(20 \mathrm{mg} \mathrm{ml}^{-1}\right.$ Promega). Lysate was then purified using the DNeasy Blood and Tissue Kit (Qiagen) spin column filters following manufacturer protocols. Purified DNA was fluorometrically quantified using a high sensitivity (HS) double-stranded DNA (dsDNA) assay on a Qubit 2.0 fluorometer following manufacturer protocols (ThermoFisher Scientific).

Sample as well as extraction control DNA were diluted 1:100 in UV-sterilized PCR-grade $\mathrm{H}_{2} \mathrm{O}$, and $1 \mu \mathrm{l}$ was used in a PCR reaction. One PCR negative control sample was included by adding $1 \mu \mathrm{l}$ of PCRgrade $\mathrm{H}_{2} \mathrm{O}$ to a PCR reaction. Two Human Microbiome Project mock communities - (1) Genomic DNA from Microbial Mock Community B (even, low concentration), v5.1L, for 16S rRNA Gene Sequencing, HM-782D and (2) Genomic DNA from Microbial Mock Community B (staggered, low concentration), v5.2L, for 16S rRNA Gene Sequencing, HM-783D (BEI Resources, ATCC) - were included as additional controls. One $\mu \mathrm{l}$ of each mock community was used in a PCR reaction. Barcoded primers recommended by the Earth Microbiome Project, 515F (Parada et al. 2016) and 806R (Apprill et al. 2015), were used to amplify the V4 region of the small subunit (SSU) rRNA gene in bacteria and archaea. Triplicate $25 \mu \mathrm{l}$ reactions contained 1.25 units of GoTaq DNA Polymerase (Promega), $0.2 \mu \mathrm{M}$ forward and reverse primers, $0.2 \mathrm{mM}$ deoxynucleoside triphosphate (dNTP) mix (Promega), $2.5 \mathrm{mM} \mathrm{MgCl}_{2}, 5 \mu \mathrm{l}$ GoTaq 5X colorless flexi buffer (Promega), and nuclease-free water. The reactions were run on a Bio-Rad Thermocycler using the following criteria: denaturation at $95^{\circ} \mathrm{C}$ for $2 \mathrm{~min}$; 28 cycles at $95^{\circ} \mathrm{C}$ for $20 \mathrm{~s}, 55^{\circ} \mathrm{C}$ for $15 \mathrm{~s}$, and $72^{\circ} \mathrm{C}$ for $5 \mathrm{~min}$; and extension at $72^{\circ} \mathrm{C}$ for $10 \mathrm{~min}$. Successful amplification was verified by running $5 \mu \mathrm{l}$ of product on a $1 \%$ agarose-Tris-borate-EDTA (TBE) gel stained with SYBR Safe gel stain (Invitrogen). Triplicate PCR products per sample were pooled and purified using the MinElute PCR purification kit (Qiagen). The concentrations of purified products were quantified using the HS dsDNA assay on the Qubit 2.0 fluorometer (ThermoFisher Scientific). Barcoded PCR products were diluted to equal concentrations and pooled for sequencing. Samples were shipped to the Georgia 
Genomics and Bioinformatics Core at the University of Georgia for sequencing on an Illumina MiSeq using paired-end $250 \mathrm{bp}$ sequencing.

\subsection{Data analysis}

All sequence processing and data analysis was performed in R Studio (v 1.1.463) running R (v 3.4.0, 2017-04-21). All code and data used for recreating figures is publicly available on GitHub (https://github. com/CynthiaBecker/USVItide). Sequence reads were inspected for quality, filtered, trimmed, and dereplicated in the DADA2 R package (v.1.10.0) (Callahan et al. 2016). Specific filtering parameters used included the following: truncLen $=\mathrm{c}(240,200), \max N=0$, maxEE $=\mathrm{c}(2,2)$, rm.phix $=$ TRUE, and compress $=$ TRUE. The parameter truncLen was used to truncate forward reads at $240 \mathrm{bp}$, and reverse reads at $200 \mathrm{bp}$ where observed quality began to drop significantly, or below a Q30 of 25. maxN was set to zero and and maxEE was set to 2 for both forward and reverse reads, which were not changed from default values because they did not lead to drastic losses in sequence read data. The parameters rm.phix $=$ TRUE and compress $=$ TRUE were included as default parameters. DADA2 was also used to remove chimeras and generate amplicon sequence variants (ASVs), which are of finer resolution and more tractable than standard operational taxonomic units (Callahan et al. 2017). Each ASV in the following analyses contains a corresponding DNA sequence that is provided in Table $\mathrm{S} 1$ in the Supplement (available at www.int-res.com/articles/ suppl/a085p101_supp.xlsx). ASV generation in DADA2 retained between 75.9 and $87.6 \%$ of input sequence reads in non-control samples, while control samples (DNA extraction controls and sequenced PCR negative controls) retained only $5.1-46.0 \%$ of input sequences (Table S2 in the Supplement). Taxonomy was assigned in DADA2 using the SILVA SSU rRNA database down to the species level where applicable (v.132) (Quast et al. 2013). Two mock community samples from the Human Microbiome Project (even and staggered) were used to check accuracy of DADA2. DADA2 inferred 29 ASVs in the even mock community and 21 ASVs in the staggered mock community and, of those, 22 and 18 ASVs were exact matches to the reference sequences, respectively. This indicated that DADA2 accurately recovered ASVs representative of the input strains.

To understand the variability in microbial communities over time at all sites, ASV counts in each sample were transformed to relative abundance, and then Bray-Curtis dissimilarity was calculated between each sample using the $\mathrm{R}$ package vegan (v2.5.4) (Oksanen et al. 2019). The resulting dissimilarity values were illustrated using non-metric multidimensional scaling (NMDS) with the R package, ggplot2 (v3.2.1) (Wickham 2016). Environmental vectors that significantly associated (cutoff $p<0.01$ ) with the ordination were produced using the function envfit in the vegan R package. Pairwise dissimilarity was plotted to represent the range of dissimilarity in microbial communities over $48 \mathrm{~h}$ at each site. A Kruskal-Wallis test was used to examine if there was a significant difference in dissimilarity between sites (significance level $\mathrm{p}<0.05$ ). To determine which pairs of locations had significantly different dissimilarities, a pairwise Wilcoxon Rank Sum test was used with a Benjamini-Hochberg correction for multiple testing and a cutoff of 0.05 .

Differential abundance (DA) of ASVs in relation to the tide was only evaluated for select samples (Fish Bay mangrove and Lameshur mangrove subtidal) using the corncob R package (v 0.1.0) (Martin et al. 2020). All ASV counts per sample were input into the corncob program, which modeled relative abundances using a logit-link for mean and dispersion. DA was modeled as a linear function of tide height (a continuous covariate that is representative of the tidal level) while controlling for differential variance and the effect of site and day or night on DA. Controlling for the effect of day or night was imperative because over the $48 \mathrm{~h}$ period low and flood tide occurred during the day, and high and ebb tide occurred during night and dawn, respectively. The parametric Wald test was used to test the hypotheses that the relative abundance of a given ASV changed significantly with respect to tide height, and the Benjamini-Hochberg false discovery rate (FDR) correction was applied to account for multiple comparisons, with the cutoff at 0.05 .

\section{RESULTS}

\subsection{Environmental characteristics}

Temperature and salinity of surface seawater fluctuated more at the mangroves (Fish Bay and Lameshur mangrove subtidal) compared to the seagrass and reef habitats (Fig. 2). At all sites, temperature was generally highest at flood or low tide. This pattern coincided with a daylight warming period (black and white bar, Fig. 2). While the temperature tracked with the diel cycle, salinity did not fluctuate more 

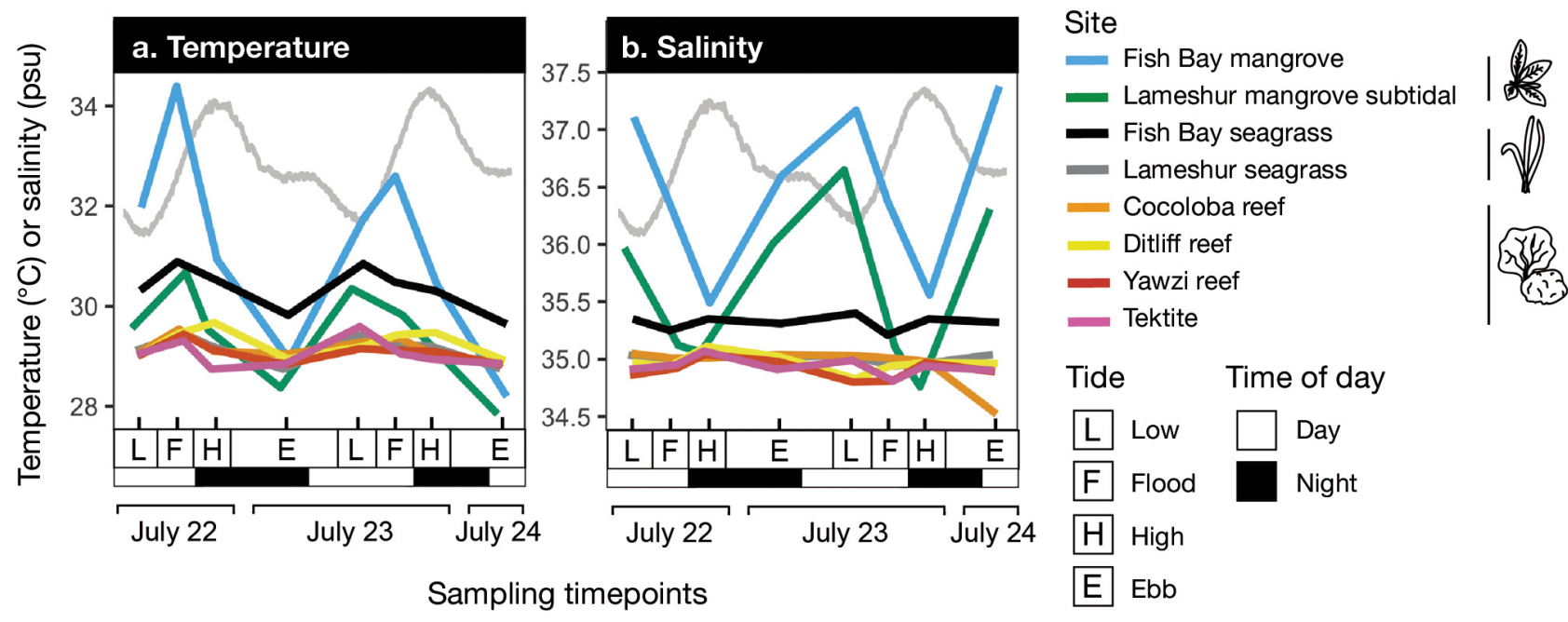

Fig. 2. Temperature and salinity over $48 \mathrm{~h}$ at each site. Line graphs of (a) temperature $\left({ }^{\circ} \mathrm{C}\right)$ and (b) salinity (psu) in the seawater over the course of the study at each site. Sample time points on the $x$-axis coincide with low $(\mathrm{L})$, flood (F), high (H), and ebb (E) tide. Tide height over the sampling period is represented in each panel (light gray line in top half of graph). Night and day represented by black and white, respectively, in the bar at the bottom of each graph

than $2.0 \%(0.69 \mathrm{psu})$ of the average salinity over the $48 \mathrm{~h}$ window at reef and seagrass locations (Fig. 2b). In contrast, salinity at mangrove sites fluctuated much more, and in concert with the tidal cycle. Fish Bay and Lameshur mangrove salinities increased above the average minimum salinities (35.5 and 34.9, respectively) by as much as $5.3 \%(1.88)$ and $4.8 \%$ (1.70), respectively (Fig. 2b). The lowest mangrove salinity was observed during high tide at the Lameshur mangrove subtidal area, which reached on average 34.9 and matched average reef water salinity. The highest mangrove site salinity was measured at Fish Bay mangrove, during low or ebb tide, and was on average 37.2 (4.8\% higher, Fig. 2b). In general, Fish Bay mangrove and seagrass habitats were more saline than those in Lameshur Bay (Fig. 2b).

Nutrient concentrations for phosphate $\left(\mathrm{PO}_{4}{ }^{3-}\right)$, ammonium $\left(\mathrm{NH}_{4}^{+}\right)$, silicate, and nitrite + nitrate $\left(\mathrm{NO}_{2}{ }^{-}+\mathrm{NO}_{3}{ }^{-}\right)$were generally lower and more stable at all reef and seagrass habitats in comparison to the mangroves (Fig. 3). Reef and seagrass habitats were oligotrophic, with all reefs experiencing average nutrient concentrations of $0.18 \mu \mathrm{M} \mathrm{PO}_{4}{ }^{3-}, 0.16 \mu \mathrm{M}$ $\mathrm{NH}_{4}{ }^{+}, 2.32 \mu \mathrm{M}$ silicate, and $0.17 \mu \mathrm{M} \mathrm{NO}_{2}{ }^{-}+\mathrm{NO}_{3}{ }^{-}$. Nutrient concentrations at seagrass locations measured on average $0.20 \mu \mathrm{M} \mathrm{PO}_{4}{ }^{3-}, 0.23 \mu \mathrm{M} \mathrm{NH}_{4}{ }^{+}, 2.58$ $\mu \mathrm{M}$ silicate, and $0.10 \mu \mathrm{M} \mathrm{NO}_{2}{ }^{-}+\mathrm{NO}_{3}{ }^{-}$. Mangrove nutrient concentrations were higher on average compared to reef and seagrass habitats, and measured $0.30 \mu \mathrm{M} \mathrm{PO}_{4}{ }^{3-}, 1.05 \mu \mathrm{M} \mathrm{NH}_{4}{ }^{+}, 4.27 \mu \mathrm{M}$ silicate, and $0.39 \mathrm{\mu M} \mathrm{NO}_{2}{ }^{-}+\mathrm{NO}_{3}{ }^{-}$. Nutrient concentrations were also more variable at the mangroves. $\mathrm{PO}_{4}{ }^{3-}, \mathrm{NH}_{4}{ }^{+}$, and silicate concentrations were lowest in the mangroves during flood and high tide, when they approached typical reef and seagrass site concentrations (Fig. 3a-c). In contrast, the highest concentrations of $\mathrm{PO}_{4}{ }^{3-}, \mathrm{NH}_{4}{ }^{+}$, and silicate at the mangroves were generally sampled during ebb and low tide (Fig. 3a-c). One exception was the Lameshur mangrove inlet, which was located near the top of the intertidal zone and could only be sampled at high tide when it was flooded. That site contained generally high concentrations of $\mathrm{PO}_{4}{ }^{3-}, \mathrm{NH}_{4}{ }^{+}$, and silicate. The Fish Bay mangrove had lower average nitrogen concentrations $\left(0.08 \mu \mathrm{M} \mathrm{NO}_{2}{ }^{-}+\mathrm{NO}_{3}{ }^{-}\right)$compared to those at both Lameshur mangrove sites $(0.68 \mu \mathrm{M}$ $\mathrm{NO}_{2}{ }^{-}+\mathrm{NO}_{3}{ }^{-}$, Fig. 3d). At Lameshur mangrove subtidal, concentrations of $\mathrm{NO}_{2}{ }^{-}+\mathrm{NO}_{3}{ }^{-}$were lowest during high tide (Fig. 3d).

\subsection{Microbial cell abundances}

While reef sites exhibited predominantly stable nutrient and physical characteristics, picocyanobacterial abundances (Prochlorococcus and Synechococcus) were highly variable and exhibited dynamics that coincided with both diel and tidal cycles (Fig. 4). Abundances of Prochlorococcus and Synechococcus decreased during the day and increased during the night. At reef sites, excluding Ditliff, the concentrations of Prochlorococcus increased up to a factor of 2 between dusk and later in the evening (between flood and high tide) on July 22 (Fig. 4a). One excep- 


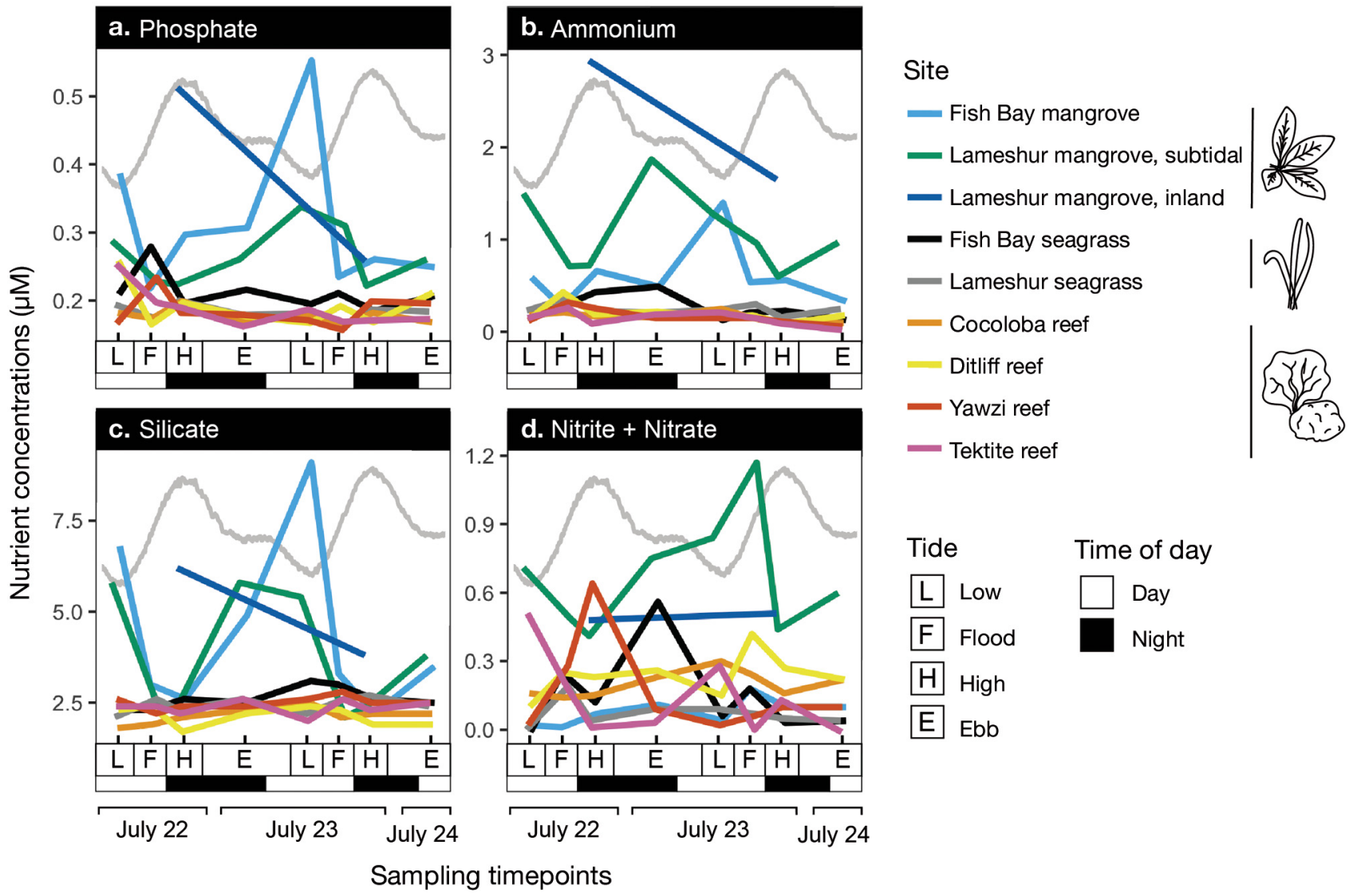

Fig. 3. Inorganic nutrient concentrations over $48 \mathrm{~h}$ at each site. Line graphs of (a) phosphate $\left(\mathrm{PO}_{4}{ }^{3-}\right),(\mathrm{b})$ ammonium (NH$\left.{ }_{4}^{+}\right),(\mathrm{c})$ silicate, and (d) nitrite + nitrate $\left(\mathrm{NO}_{2}{ }^{-}+\mathrm{NO}_{3}{ }^{-}\right)$in the seawater over the course of the study at each site. Sample time points on the $x$-axis represent low $(\mathrm{L})$, flood $(\mathrm{F})$, high $(\mathrm{H})$, and ebb $(\mathrm{E})$ tide. Tide height over the sampling period is represented in each panel (light gray line in top half of graph). Night and day represented by black and white, respectively, in the bar at the bottom of each graph

tion to this trend was at the Ditliff reef (yellow line, Fig. 4a), where Prochlorococcus abundance decreased by $50 \%$ between flood and high tide on July 22 . This changed on July 23, when abundances of Prochlorococcus at Ditliff and all other reefs increased between dusk (flood tide) and night (high tide). In general, Prochlorococcus cells were greatest at night and before dawn during high or ebb tide, and lowest in abundance during the day at low and flood tide (Fig. 4a). Abundances of Prochlorococcus were low at Fish Bay seagrass (average $15333 \mathrm{cells} \mathrm{ml}^{-1}$ ) and nonexistent at Fish Bay mangrove. In contrast to Prochlorococcus, Synechococcus abundances could be measured at all sites, where they exhibited cyclical changes. At all sites, a clear change in abundance was present between dusk and night over both days (flood to high tide). During that time period on July 22, Synechococcus abundances increased by a factor of 1.70-9.30, and on July 23 the cells increased by a factor of 1.45-17.3 (Fig. 4b). Synechococcus abundances also tracked closely to the tidal cycle, with increased cell abundances during flood tide and decreased abundances during ebb tide. The highest abundances coincided with high tide on both days. Synechococcus abundances were low during ebb or flood tide on both days (Fig. 4b). A sudden increase in photosynthetic picoeukaryotes between dusk and night time points was also observed at reef and seagrass habitats, which also coordinated with tidal cycle, where the lowest abundances occurred during flood tide, followed by a sharp increase until high tide (Fig. 4d). Picoeukaryotes in the mangroves exhibited higher variability that was not coordinated with tidal or diel cycles over $48 \mathrm{~h}$. Abundances of heterotrophic Bacteria and Archaea were greatest at both mangroves (Fish Bay and Lameshur mangrove subtidal) during low tide and at the Lameshur mangrove inland site that was only sampled at high tide. Fish Bay seagrass and mangroves contained more heterotrophic Bacteria and Archaea compared to 


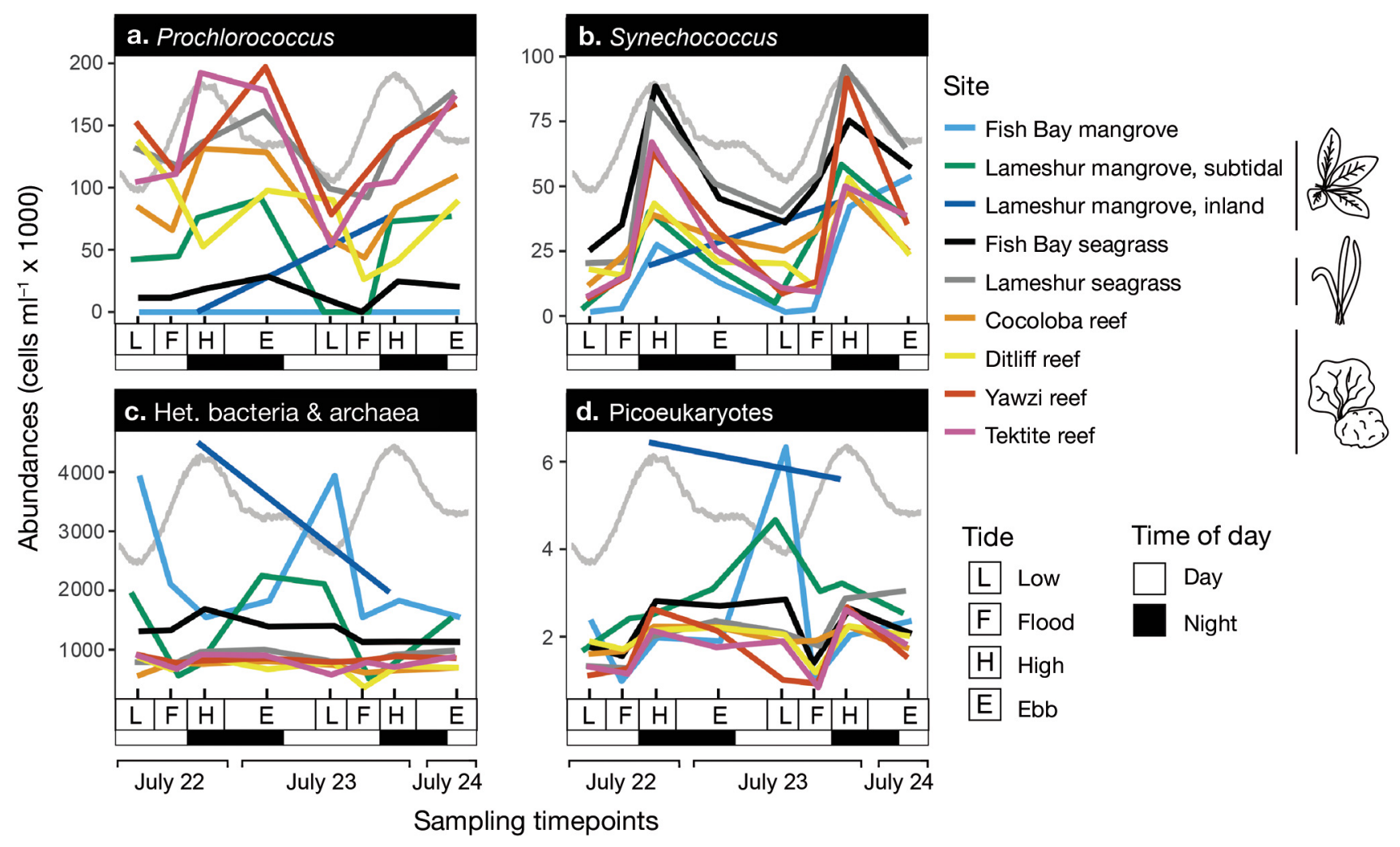

Fig. 4. Cell abundances from flow cytometry over $48 \mathrm{~h}$ at each site. Line graphs of (a) Prochlorococcus, (b) Synechococcus, (c) heterotrophic (unpigmented) bacteria and archaea, and (d) picoeukaryotes over the course of the study at each site. Sample time points on the $x$-axis represent low $(\mathrm{L})$, flood $(\mathrm{F})$, high $(\mathrm{H})$, and ebb $(\mathrm{E})$ tide. Tide height over the sampling period is represented in each panel (light gray line in top half of graph). Night and day represented by black and white, respectively, in the bar at the bottom of each graph

Lameshur Bay seagrass and mangrove locations (Fig. 4c). At the Lameshur mangrove subtidal area during flood and high tide, the abundance of heterotrophic Bacteria and Archaea decreased to 635646 cells $\mathrm{ml}^{-1}$ on average, similar to abundances at Lameshur seagrass and all coral reef sites. Coral reef and seagrass biomes exhibited stable heterotrophic bacterial and archaeal abundances compared to both mangrove biomes (Fig. 4c).

\subsection{Variability in microbial communities with tides}

NMDS of Bray-Curtis dissimilarity revealed that reef and seagrass seawater microbial community compositions were distinct from those at mangrove habitats (Fig. 5a). The overlaid environmental vectors indicated that mangroves featured increased nutrient concentrations, salinity, heterotrophic bacterial and archaeal abundances, and picoeukaryote abundances compared to reef and seagrass habitats (Fig. 5a).
Fish Bay sites (mangrove and seagrass), located outside of the National Park, clustered separately from all other reef, mangrove, and seagrass sites, which corresponded with increased temperature at those sites (Fig. 5a, black and light blue dots). Conversely, dissimilarity of Fish Bay seagrass microbial communities was significantly different than all other sites (Fig. 5c, Table A1 in the Appendix). Reef sites generally clustered together with Lameshur seagrass sites in the NMDS plot (Fig. 5a), and a bar chart representation of the within-site Bray-Curtis dissimilarity at each site (beta diversity) revealed similar trends between reef and Lameshur seagrass sites (Fig. 5c, Table A1). Vectors associated with increased depth and Prochlorococcus cell abundances pointed in the direction of the reef and Lameshur Bay seagrass sites, which verified cell abundance trends captured earlier (Fig. 4a \& 5a). Fish Bay seagrass, Lameshur seagrass, Yawzi reef, and Tektite reef samples clustered tightly within site, which suggested little change in community composition over $48 \mathrm{~h}$ (Fig. 5a). Ditliff and Cocoloba reef microbial community compositions did 

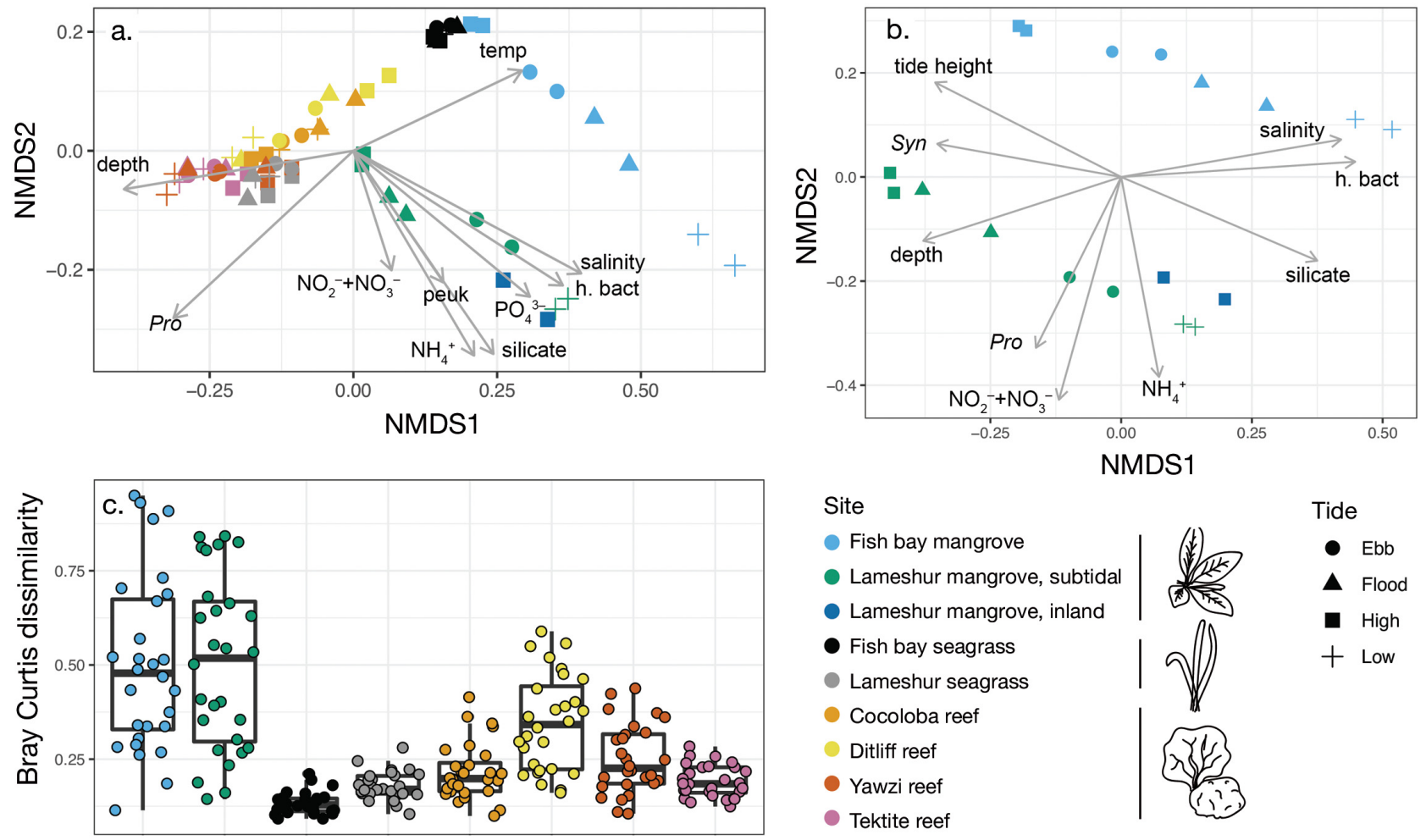

Tide

- Ebb

$\Delta$ Flood

- High

+ Low

Fig. 5. Non-metric multidimensional scaling (NMDS) and boxplots representing Bray-Curtis dissimilarity between microbial communities, obtained from SSU rRNA gene sequencing. Bray-Curtis dissimilarity between samples represented by NMDS with vectors of environmental variables overlaid either (a) all samples or (b) mangrove samples collected over 48 h. Vectors point in the direction of the greatest change in the variable or gradient they represent; length of the vector is proportional to the strength of the gradient. Only vectors with a $\mathrm{p}<0.01$ are represented. (c) Boxplots represent pairwise Bray-Curtis dissimilarity for samples within each site. Boxplots represent the interquartile range (IQR), or the area between the 25 and $75 \%$ quantiles with the median as the line in the center. Lines extend beyond the box to $1.5 \times$ IQR. Points beyond the lines are outliers. Pro: Prochlorococcus; Syn: Synechococcus; peuk: picoeukaryotes; h. bact: heterotrophic bacteria and archaea; temp = temperature

not cluster as tightly, which indicated greater variability over 48 h (Fig. 5a).

Microbial community composition at the Fish Bay and Lameshur mangrove sites exhibited a pattern of organization that represents a tidally influenced shift (Fig. 5b). The spread of points in the NMDS was organized with high tide samples (squares) farthest from low tide samples (crosses), and flood and ebb samples in between. Overlaid vectors revealed that tide height and silicate were significantly associated with the ordination of mangrove microbial community composition (Fig. 5a,b). In the mangrove microbial communities, high tide microbial composition (squares) were oriented in the direction of highest tide height and lowest silicate concentrations, while low tide community composition (crosses) were in the direction of the lowest tide height and highest silicate concentrations (Fig. 5b). In the NMDS, the Lameshur mangrove inland microbial communities sampled at high tide only were positioned closest to the low tide Lameshur mangrove subtidal communities. The overlaid vectors also revealed that the Fish Bay mangrove site had increased salinity and heterotrophic bacteria and archaea, especially at low tide (Fig. 5b). The Lameshur mangrove subtidal site, on the other hand, was deeper and contained high abundances of Synechococcus at high tide, had more Prochlorococcus, and featured higher nitrogen concentrations (Fig. 5b). Furthermore, tidal changes in Fish Bay mangrove featured cycles in the relative abundances of Bacteroidetes, Epsilonbacteraeota, and Proteobacteria while Lameshur mangrove subtidal exhibited cycles in the relative abundances of Bacteroidetes, Cyanobacteria, and Proteobacteria (Fig. A1 in the Appendix).

To further investigate the variability in microbial community structure at each site over $48 \mathrm{~h}$, we examined pairwise Bray-Curtis dissimilarity of communities within each site (Fig. 5c). Higher pairwise dissimilarity overall indicated a more variable microbial 
community composition while a lower and less variable within-site dissimilarity indicated greater stability in the microbial community composition. Withinsite dissimilarity was significantly different across sites (Kruskal-Wallis test, $\mathrm{p}<0.05$ ). Pairwise Wilcoxon rank sum tests revealed that within-site dissimilarity was significantly lower at all sites compared to mangrove sites ( $p<0.05$, Table A1) but not significantly different between mangrove sites $(p=$ 0.9805 , Table A1). All pairwise comparisons are summarized in Table A1.

\subsection{Differential abundance of ASVs at mangrove sites with tide height}

To investigate which taxa were changing with respect to tide height in the mangroves, we tested for significantly differentially abundant (DA) ASVs in relation to tide height and found 87 DA ASVs (Fig. 6). DA ASVs were classified into 24 taxonomic orders (ASV68 was unclassified at the order level). The majority of DA ASVs $(82.8 \% ; 72$ ASVs) had a positive coefficient and $17.2 \%$ (15 ASVs) had a negative coefficient. This indicated that most DA ASVs were enriched with a 1 unit increase in tide height and were therefore enriched during high tide. Some of these significantly enriched high tide ASVs were classified to Proteobacteria, including SAR11, SAR86, and AEGEAN-169 marine group, 'Candidatus Actinomarina' (phylum Actinobacteria), and NS5 marine group (phylum Bacteroidetes) (Fig. 6). Many ASVs of Flavobacteriales (phylum Bacteroidetes), SAR116 (phylum Proteobacteria), and 'Cyanobacteria' (Prochlorococcus and Synechococcus) were also significantly associated to a high tide height in mangrove environments (Fig. 6).

The ASVs with a negative coefficient decreased in relative abundance with a 1 unit increase in tide height and therefore were enriched during low tide heights in the mangrove environment. Significant low tide associated ASVs were classified to phyla that changed dramatically in mangroves as visualized in the stacked bar chart, and included Epsilonbacteraeota (Arcobacter), Proteobacteria (OM27 clade of Bdellovibrionaceae, Marinobacterium, Micropepsis and Rhodobacteraceae), and Bacteroidetes (Draconibacterium) (Figs. A1 \& 6). The bacteria significantly enriched during low tide were distinct from the bacteria that were significantly enriched during high tide, and included unique orders such as Bacteroidales (genus Draconibacterium) and Micropepsales (genus Micropepsis) (Fig. 6). Differentially abundant ASVs revealed a shifting microbial community with tidal cycle, specifically as it pertained to changes in tide height, which confirmed trends seen in the NMDS analysis (Figs. 5b \& 6).

\section{DISCUSSION}

We used a combination of genomic and environmental measurements to determine the extent of tidally influenced microbial dynamics in 3 important and spatially related tropical biomes: mangroves, seagrass meadows, and coral reefs. Not all bays and areas offered the same biome structure, but Lameshur and Fish bays offered comparable biome patterns of mangroves, seagrasses, and coral reefs as we moved southward, allowing for biome replication. We found a significant tide-mediated change in environmental and microbial parameters in mangrove environments. Furthermore, differential abundance analysis identified microbial taxa that were significantly associated with changing tidal elevation. In contrast, seawater overlying reefs and seagrass meadows exhibited strong cyclic changes in picocyanobacterial abundances, despite muted changes in physicochemical variables, nutrient concentrations and microbial community composition. Overall, our findings underpin how short-term tidal and likely also diel cycles influence the microbial dynamics of coastal tropical ecosystems.

Mangrove regions sampled in this study (Fish Bay mangrove and Lameshur mangrove subtidal) were surrounded by red mangroves. Red mangroves are characterized by prop roots that extend into the seawater and sediment and are constantly immersed in seawater. The Lameshur mangrove inland site at the upper intertidal zone was surrounded by black and white mangroves and only flooded during high tide. Over the course of our study, these biomes were characterized by variable salinity, nutrient concentrations, and heterotrophic bacteria and archaea that coincided with different parts of the tidal cycle, a common finding that has previously been reported (Dittmar \& Lara 2001, Sánchez-Carrillo et al. 2009). While seawater flux was not measured here, the data suggest that the tidal flow of seawater from the oligotrophic reef and seagrass biomes into the more eutrophic mangrove ecosystem during flood and high tide promoted depression of salinity, nutrient, and heterotrophic microbial regimes. During ebb and low tide, higher nutrients and heterotrophic bacteria and archaea in the mangroves may have been caused by the seawater flushing out from the upper 


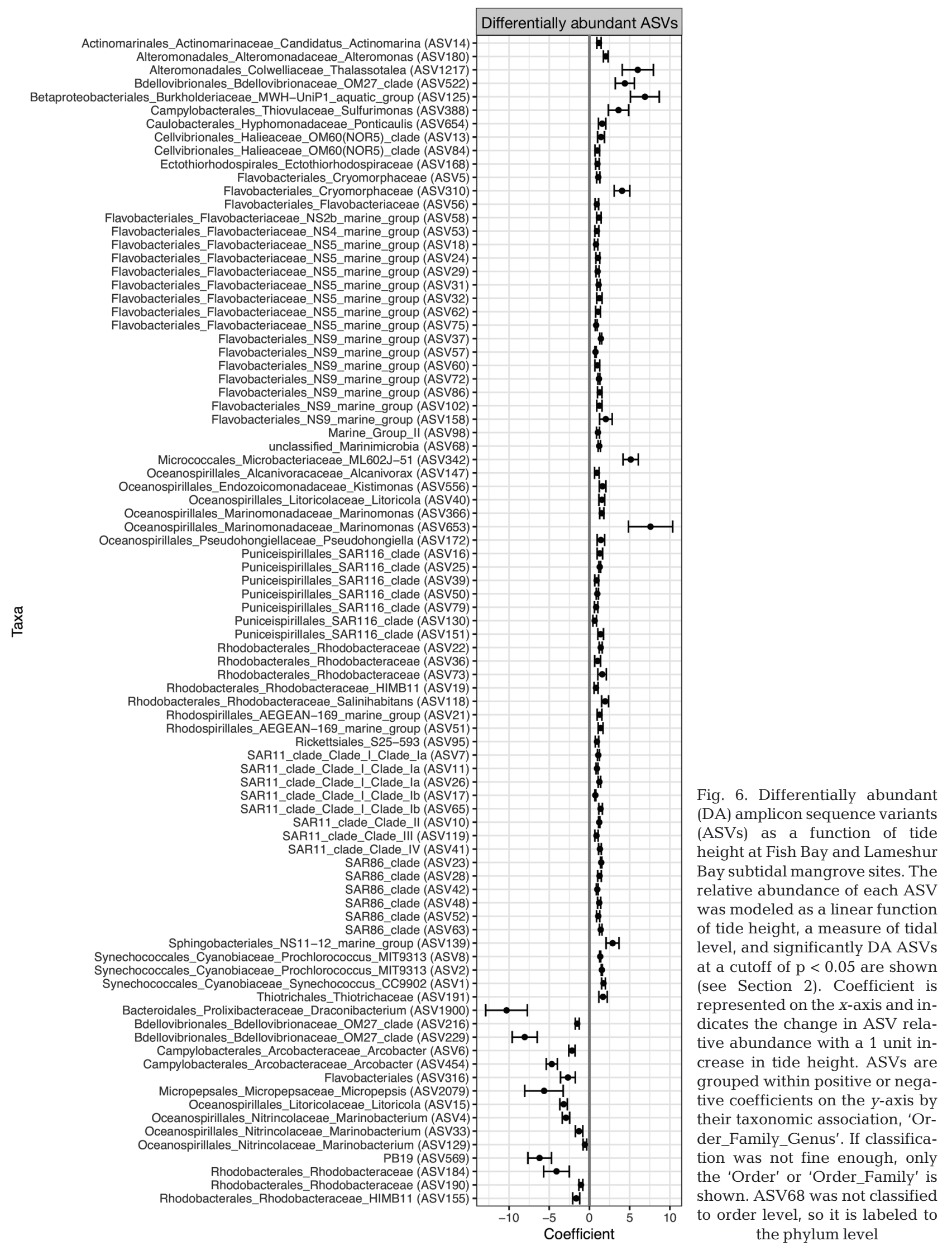


intertidal black and white mangrove forest that was enriched in heterotrophic Bacteria and Archaea as well as some nutrients to the fringing and subtidal red mangrove forest. In contrast, the higher salinity was likely more due to evaporation of seawater during the day than due to tidal mixing.

Compared to mangroves, reef and seagrass meadows were characterized by consistent physicochemical parameters and heterotrophic bacterial and archaeal cell abundances. Despite this, picocyanobacterial (Prochlorococcus and Synechococcus) abundances were variable over the $48 \mathrm{~h}$ sampling window, which appeared to be related to both tidal and diurnal cycles. Blanchot et al. (1997) noted a similar pattern in Prochlorococcus and picoeukaryotes in the equatorial Pacific, where cell abundances increased from dusk to 02:00 h, then began to decrease until dusk the following day over 5 consecutive days. This study was not coastal, and therefore unrelated to tides. Additionally, diel-influenced abundances of picocyanobacteria were recently identified on a coral reef just east of the reefs sampled in this study, with Prochlorococcus doubling and Synechococcus increasing each night, and not in relation to the tides (Weber \& Apprill 2020). These daily cycles were a result of cell growth, where cells divided in late afternoon or evening, resulting in a doubling of the community for well-synchronized populations (Vaulot \& Marie 1999, Binder \& DuRand 2002). Given the photosynthetic capability of these cells, the changes we note in our study were most likely due to growth resulting from changes in light or diel rhythms rather than changes in tide. However, because low and flood tide coincided with daytime and high and ebb tide coincided with night, we were unable to fully disentangle the effects of tide compared to light in our study. We noted the complete absence of Prochlorococcus cells at the Fish Bay mangrove, but not at Lameshur mangrove subtidal. This may have been due to the higher temperature, salinity and phosphate concentrations in Fish Bay compared to Lameshur Bay, which may collectively make this environment inhospitable for Prochlorococcus (Partensky et al. 1999).

The tidal variability in seawater microbial communities within the mangrove biomes mirrored trends seen in the physicochemical environment. Lu et al. (2015) found that over diurnal periods in a coastal estuarine to reef transition zone, the changes in microbial communities were more likely due to tidal mixing of the seawater rather than growth due to altered environmental conditions. While $\mathrm{Lu}$ et al. (2015) did not find tidal changes in environmental variables to correlate well with microbial community composition in estuarine environments, other studies did find that environmental variables such as salinity and inorganic nutrients can impact the structure of microbial communities (Bouvier \& del Giorgio 2002, Campbell \& Kirchman 2013). Our study showed both biological and physical processes to be related to observed changes in microbial communities over short, tidal time scales within the mangroves. In our study, tidal mixing likely exerted the greatest impact on microbial communities within mangrove environments, and was additionally responsible for the changes in the environmental parameters. However, it was challenging to disentangle whether altered microbial communities were a growth response to changing environmental conditions or due to tidally advected communities reflective of the environment of origin.

Regardless, the observed short-term changes (several hours and over the course of day) highlight the limitation of snapshot (e.g. once daily) sampling. All sites showed some daily or tidal-based variation. Thus, long-term sampling schemes aimed at characterizing the nutrient and microbial diversity of a location should consider the importance of short temporal variation and at least sample over a few diel cycles to account for this variability and evaluate its consistency (or lack thereof) over time. Sampling schemes designed to characterize microbial communities and biogeochemistry may be particularly important for monitoring the health and stability of the region within marine reserves, a concept that has had success in coral reef environments (Glasl et al. 2017 , 2018). To alleviate misleading results that may stem from sampling design, we suggest that accounting for tidal or diurnal forces is important in these coastal areas. In our study of coral reef and seagrass meadow seawater, the striking changes in picocyanobacteria over $2 \mathrm{~d}$ underpin the importance of sampling at the same time each day, when possible. In contrast, the dramatic tidally induced changes in the coastal mangrove seawater complicate monitoring efforts. In this case, efforts to sample mangrove environments during a consistent part of the tide cycle (especially ebb or low tide) would allow for a more controlled study of the mangrove seawater. In this way, the temporal microbial community dynamics of the seawater ecosystem would be both controlled for and well characterized.

Beyond tide-related changes in mangrove seawater microbial communities, there were site-specific changes that may be explained by differences in the environmental variables at each mangrove environ- 
ment. A study of soil microbiomes at a protected and unprotected mangrove area also noted distinct sitespecific changes that were explained by strikingly different environmental factors (Yun et al. 2017). That study was similar to ours because it sampled a protected and unprotected mangrove area. The Lameshur mangrove in our study was within the Virgin Islands National Park, with minimal coastal development. In contrast, the Fish Bay coast and watershed area is considered impacted by human development and has been a target of management due to erosion and sedimentation from such development and bay contamination from septic systems, household pollutants, and pesticides (Hodge et al. 2001). Both Yun et al. (2017) and the present study included only one protected and unprotected site, so it remains to be seen if the environmental and microbial changes between regions were explained by protective status. However, the reproducibility across studies suggests there may be some actual differences in microbial communities between human-influenced and more pristine mangrove habitats that could be a target for future studies of mangrove ecosystems. These changes across bays may also illustrate the natural heterogeneity of mangrove habitats (Leung 2015). For instance, Fish Bay mangrove contains a habitat of red mangroves that surround the sandy shoreline, while Lameshur Bay mangrove extends from a rocky outlet to an inland mangrove swamp with multiple species of mangrove in muddy sediment. How human influence and natural heterogeneity together influence the structure of microbial communities or how microbes play a role in mangrove habitat health and potential recovery are outstanding questions for target in future studies.

Our analysis of DA ASVs at mangroves indicated that tidal mixing may be bringing in microbial cells from the reef and seagrass environments, causing significant changes in community composition especially during flood and high tide. SAR11, SAR86, 'Candidatus Actinomarina', NS5 marine group, AEGEAN-169 marine group, and Rhodobacteraceae were enriched at higher tides within coastal mangrove seawater. These taxa were also shown to be significantly associated with reef seawater by a study that compared seawater microbiomes near and far from corals on Caribbean reefs (Weber et al. 2019). In the mangroves during high tide, we also identified other microbes that were typical of reef seawater or open ocean microbial communities, including Prochlorococcus and Synechcococcus, several Proteobacteria, including OM60 clade, SAR116 clade, Oceanospirillales, and Rickettsiales, many Bacteroi- detes including Cryomorphaceae, NS9 marine group, Flavobacteriaceae (NS4 marine group and NS2b marine group), NS11-12 marine group, and the Archaea Marine Group II (Euryarchaeota) (Nelson et al. 2011, Kelly et al. 2014, Apprill et al. 2015, Choi et al. 2015, Lindh et al. 2015, Polónia et al. 2016, Becker et al. 2017, Kim et al. 2018, Glasl et al. 2019).

Tidal elevation appeared to exert a mixed effect on Bdellovibrionaceae, a family of Proteobacteria that was significantly enriched at both low and high tides. Bdellovibrionaceae are bacterial predators and have been previously found at increased abundance in mangrove ecosystems compared to coral reef environments, which was likely due to the heightened prey available in the mangrove environment (Sutton $\&$ Besant 1994). In our study, the increased heterotrophic bacteria and archaea during ebb and low tide may have provided an environment with abundant prey that fostered growth of Bdellovibrionaceae. In contrast, the presence of a high tide-associated Bdellovibrionaceae ASV (ASV522) may have indicated the influx of a coral reef or seagrass-associated strain with different environmental growth tolerances and prey preferences (Sutton \& Besant 1994). While confirming the exact specific Bdellovibrionaceae strains within the OM27 clade was not possible here, the presence of differentially abundant Bdellovibrionaceae cells within the mangrove habitat underlines a potentially important role of Bdellovibrionaceae within mangrove ecosystems that warrants further investigation.

While tidal mixing exerted varied influences on Bdellovibrionaceae taxa, during low tide height, enrichment of microbial cells likely derived from mangrove seawater and sediment was apparent. For example, 3 DA ASVs classified as Marinobacterium, a gammaproteobacterial genus that has previously been associated with estuarine or mangrove ecosystems (Chen et al. 2010, Alfaro-Espinoza \& Ullrich 2014, Park et al. 2016). Two low tide-associated ASVs were classified as Arcobacter (ASV6, ASV454), a genus of the order Campylobacteria that has been found enriched in intertidal sediment (Wang et al. 2012). While most Arcobacter species have been isolated using aerobic or microaerobic conditions (Collado \& Figueras 2011), some, such as a species isolated from estuarine sediment, grew anaerobically (Sasi Jyothsna et al. 2013). Micropepsis (ASV2079) is a recently identified genus of Alphaproteobacteria, with one obligatory anaerobic isolate originating from an oligotrophic bog-like environment (Harbison et al. 2017). The anaerobic lifestyles of Micropepsis and potentially Arcobacter suggest they may have 
been derived from anoxic mangrove sediment. Draconibacterium (phylum Bacteroidetes) is another genus that contains marine sediment-derived bacteria, providing merit to the detection of this bacterium when water was shallowest (Du et al. 2014, Gwak et al. 2015). The Rhodobacteraceae (Alphaproteobacteria) are some of the most widely spread bacteria in the ocean and a study analyzing distribution and classification of Rhodobacteraceae found that onethird of the detected Rhodobacteraceae correlated to sediment parameters, indicating there are specific sediment-associated Rhodobacteraceae (Pohlner et al. 2019). Rhodobacteraceae strains have been isolated from mangrove sediments (Yu et al. 2018, Ren et al. 2019). Overall, these data suggest that during low tide, the mangrove seawater becomes enriched in microbial cells likely derived from the mangrove sediment within the inland tidal flat and mangrove forest.

This work is the first to characterize tide-influenced seawater microbial community variability at 3 distinct coastal biomes simultaneously and provides new insights into coastal microbial community dynamics over short temporal scales. Mangrove seawater microbial communities exhibited surprising variability over $48 \mathrm{~h}$, which was associated with tidal elevation. This was contrasted by the relative consistency in coral reef and seagrass meadow microbial communities sampled over the same time period. All biomes characterized in this study did show some level of short temporal changes associated with tidal or diurnal effects. While we incorporated and repeatedly sampled 8 sites, this was only conducted for $48 \mathrm{~h}$, preventing our analysis from fully disentangling the tidal and diurnal effects. Addressing this variability over longer timescales, such as several days, would help elucidate the consistency of these patterns among mangrove versus seagrass and reef seawater microbial communities. Additionally, this study lacks inclusion of organic carbon and nitrogen concentrations and dynamics. These measurements should be included in future studies, and could provide additional important insights into heterotrophic microbial population dynamics. Another future area of investigation that is relevant to monitoring practices is how the benthic microbial communities (associated with the sediments, seagrass, reef life, and surrounding reef-depth waters) may change during tidal cycles. To this end, some studies have shown evidence for short-term changes in near-coral and reef seawater microbial communities (Kelly et al. 2019, Weber \& Apprill 2020) and in seagrass and mangrove sediment microbial parameters (Moriarty \& Pollard 1982,
Lee \& Joye 2006). The investigation of microbial community changes over short-term scales in these coastal environments is still rare, and a coordinated study including multiple sample types (seawater, sediment, flora, and fauna) over such timescales would be an important target for future work. Regardless, this study provides a basis for future studies, which could investigate how shifting microbial regimes in mangrove environments impact microbial productivity and habitat processes over short temporal scales in these dynamic and critically important coastal ecosystems. Additionally, this work reinforces the importance of accounting for tidal and diurnal scales within the context of long-term investigations, especially in dynamic and protected coastal biomes.

Data accessibility. All raw sequence files used in this study were uploaded to the NCBI Sequence Read Archive under accession number PRJNA578400, and data are also available at BCO-DMO under dataset 783679 (https://www.bcodmo.org/dataset/783679). R scripts for recreating all figures included in this paper are available on GitHub (https:// github.com/CynthiaBecker/USVItide). Supplement tables are also provided on the GitHub page for reference.

Acknowledgements. We thank the Virgin Islands Environmental Resource Station and University of the Virgin Islands for field support. Thanks to Karen Selph from the University of Hawai'i School of Ocean and Earth Science and Technology (SOEST) for flow cytometry support, Joe Jennings of Oregon State University for measurement of inorganic nutrient concentrations, and the Georgia Genomics and Bioinformatics Core, which provided the sequencing support. This research was supported by NSF awards OCE1536782 to T.A.M., J.K.L., and A.A. and OCE-1736288 to A.A., NOAA Cooperative Institutes award NA19OAR4320074 to A.A. and E. Kujawinski and the Andrew W. Mellon Foundation Endowed Fund for Innovative Research to A.A.

\section{LITERATURE CITED}

Aburto-Oropeza O, Ezcurra E, Danemann G, Valdez V, Murray J, Sala E (2008) Mangroves in the Gulf of California increase fishery yields. Proc Natl Acad Sci USA 105: 10456-10459

Alfaro-Espinoza G, Ullrich MS (2014) Marinobacterium mangrovicola sp. nov., a marine nitrogen-fixing bacterium isolated from mangrove roots of Rhizophora mangle. Int J Syst Evol Microbiol 64:3988-3993

Alongi DM (1987) Intertidal zonation and seasonality of meiobenthos in tropical mangrove estuaries. Mar Biol 95: $447-458$

Apprill A, McNally S, Parsons R, Weber L (2015) Minor revision to V4 region SSU rRNA 806R gene primer greatly increases detection of SAR11 bacterioplankton. Aquat Microb Ecol 75:129-137

Armstrong F, Stearns C, Strickland J (1967) The measurement of upwelling and subsequent biological processes by means of the Technicon AutoAnalyzer and associated equipment. Deep-Sea Res 14:381-389 
Becker C, Hughen K, Mincer T, Ossolinski J, Weber L, Apprill A (2017) Impact of prawn farming effluent on coral reef water nutrients and microorganisms. Aquacult Environ Interact 9:331-346

Bernhardt H, Wilhelms A (1967) The continuous determination of low-level iron, soluble phosphate and total phosphate with the Autoanalyzer. Technicon Symp 1:385-389

Binder BJ, DuRand MD (2002) Diel cycles in surface waters of the equatorial Pacific. Deep-Sea Res II 49:2601-2617

Blanchot J, Andre JM, Navarette C, Neveux J (1997) Picophytoplankton dynamics in the equatorial Pacific: diel cycling from flow-cytometer observations. C R Acad Sci 320:925-931

Blum LK, Mills AL (1991) Microbial growth and activity during the initial stages of seagrass decomposition. Mar Ecol Prog Ser 70:73-82

Boehm AB, Weisberg SB (2005) Tidal forcing of enterococci at marine recreational beaches at fortnightly and semidiurnal frequencies. Environ Sci Technol 39:5575-5583

Bourne DG, Webster NS (2013) Coral reef bacterial communities. In: Rosenberg E, DeLong EF, Lory S, Stackebrandt E, Thompson F (eds) The prokaryotes: prokaryotic communities and ecophysiology. Springer, Berlin, p 163-187

Bouvier TC, del Giorgio PA (2002) Compositional changes in free-living bacterial communities along a salinity gradient in two temperate estuaries. Limnol Oceanogr 47:453-470

* Bulan DE, Wilantho A, Krainara P, Viyakarn V, Chavanich S, Somboonna N (2018) Spatial and seasonal variability of reef bacterial communities in the upper Gulf of Thailand. Front Mar Sci 5:441

Bunse C, Pinhassi J (2017) Marine bacterioplankton seasonal succession dynamics. Trends Microbiol 25:494-505

* Callahan BJ, McMurdie PJ, Rosen MJ, Han AW, Johnson AJA, Holmes SP (2016) DADA2: high-resolution sample inference from Illumina amplicon data. Nat Methods 13: 581-583

* Callahan BJ, McMurdie PJ, Holmes SP (2017) Exact sequence variants should replace operational taxonomic units in marker-gene data analysis. ISME J 11:2639-2643

Campbell BJ, Kirchman DL (2013) Bacterial diversity, community structure and potential growth rates along an estuarine salinity gradient. ISME J 7:210-220

Campbell L, Vaulot D (1993) Photosynthetic picoplankton community structure in the subtropical North Pacific Ocean near Hawaii (station ALOHA). Deep-Sea Res I 40: 2043-2060

* Chen WC, Tseng WN, Hsieh JL, Wang YS, Wang SL (2010) Biodegradation and microbial community changes upon shrimp shell wastes amended in mangrove river sediment. J Environ Sci Health B 45:473-477

* Chen Q, Zhao Q, Li J, Jian S, Ren H (2016) Mangrove succession enriches the sediment microbial community in South China. Sci Rep 6:27468

Chen X, Wei W, Wang J, Li H and others (2019) Tide driven microbial dynamics through virus-host interactions in the estuarine ecosystem. Water Res 160:118-129

Choi DH, Park KT, An SM, Lee K and others (2015) Pyrosequencing revealed SAR116 clade as dominant dddP-containing bacteria in oligotrophic NW Pacific Ocean. PLOS ONE 10:e0116271

Collado L, Figueras MJ (2011) Taxonomy, epidemiology, and clinical relevance of the genus Arcobacter. Clin Microbiol Rev 24:174-192

Dittmar T, Lara RJ (2001) Driving forces behind nutrient and organic matter dynamics in a mangrove tidal creek in
North Brazil. Estuar Coast Shelf Sci 52:249-259

*Donato DC, Kauffman JB, Murdiyarso D, Kurnianto S, Stidham M, Kanninen M (2011) Mangroves among the most carbon-rich forests in the tropics. Nat Geosci 4:293-297

* Du ZJ, Wang Y, Dunlap C, Rooney AP, Chen GJ (2014) Draconibacterium orientale gen. nov., sp. nov., isolated from two distinct marine environments, and proposal of Draconibacteriaceae fam. nov. Int J Syst Evol Microbiol 64: 1690-1696

* Duke NC, Meynecke JO, Dittmann S, Ellison AM and others (2007) A world without mangroves? Science 317:41-42

* Field CB, Behrenfeld M, Renderson J, Falkowski P (1998) Primary production of the biosphere: integrating terrestrial and oceanic components. Science 281:237-240

*Fuhrman JA, Hewson I, Schwalbach MS, Steele JA, Brown MV, Naeem S (2006) Annually reoccurring bacterial communities are predictable from ocean conditions. Proc Natl Acad Sci USA 103:13104-13109

*Gast GJ, Wiegman S, Wieringa E, van Duyl FC, Bak RPM (1998) Bacteria in coral reef water types: removal of cells, stimulation of growth and mineralization. Mar Ecol Prog Ser 167:37-45

Gilbert JA, Field D, Swift P, Newbold L and others (2009) The seasonal structure of microbial communities in the western English Channel. Environ Microbiol 11: 3132-3139

Glasl B, Webster NS, Bourne DG (2017) Microbial indicators as a diagnostic tool for assessing water quality and climate stress in coral reef ecosystems. Mar Biol 164:91

Glasl B, Bourne DG, Frade PR, Webster NS (2018) Establishing microbial baselines to identify indicators of coral reef health. Microbiol Aust 39:42-46

*Glasl B, Bourne DG, Frade PR, Thomas T, Schaffelke B, Webster NS (2019) Microbial indicators of environmental perturbations in coral reef ecosystems. Microbiome 7:94

* Gong B, Cao H, Peng C, Perčulija V and others (2019) Highthroughput sequencing and analysis of microbial communities in the mangrove swamps along the coast of Beibu Gulf in Guangxi, China. Sci Rep 9:9377

*Gwak JH, Kim SJ, Jung MY, Kim JG and others (2015) Draconibacterium filum sp. nov., a new species of the genus of Draconibacterium from sediment of the east coast of the Korean Peninsula. Antonie Leeuwenhoek 107: 1049-1056

* Haas AF, Nelson CE, Rohwer F, Wegley-Kelly L and others (2013) Influence of coral and algal exudates on microbially mediated reef metabolism. PeerJ 1:e108

*Harbison AB, Price LE, Flythe MD, Bräuer SL (2017) Micropepsis pineolensis gen. nov., sp. nov., a mildly acidophilic alphaproteobacterium isolated from a poor fen, and proposal of Micropepsaceae fam. nov. within Micropepsales ord. nov. Int J Syst Evol Microbiol 67:839-844

Hodge JD, Barry D, Haase E, O'Reily R, Smith H, Towle E, Wright J (2001) Fish Bay management plan for Fish Bay watershed, St. John, United States Virgin Islands. Department of Planning and Natural Resources, St. Thomas

Kelly LW, Williams GJ, Barott KL, Carlson CA and others (2014) Local genomic adaptation of coral reef-associated microbiomes to gradients of natural variability and anthropogenic stressors. Proc Natl Acad Sci USA 111: 10227-10232

Kelly LW, Nelson CE, Haas AF, Naliboff DS and others (2019) Diel population and functional synchrony of microbial communities on coral reefs. Nat Commun 10:1691

Kim H, Ducklow HW (2016) A decadal (2002-2014) analysis 
for dynamics of heterotrophic bacteria in an Antarctic coastal ecosystem: variability and physical and biogeochemical forcings. Front Mar Sci 3:214

Kim Y, Jeon J, Kwak MS, Kim GH, Koh I, Rho M (2018) Photosynthetic functions of Synechococcus in the ocean microbiomes of diverse salinity and seasons. PLOS ONE 13:e0190266

* Kirchman D, Peterson B, Juers D (1984) Bacterial growth and tidal variation in bacterial abundance in the Great Sippewissett Salt Marsh. Mar Ecol Prog Ser 19:247-259

Lee RY, Joye SB (2006) Seasonal patterns of nitrogen fixation and denitrification in oceanic mangrove habitats. Mar Ecol Prog Ser 307:127-141

Leung JYS (2015) Habitat heterogeneity affects ecological functions of macrobenthic communities in a mangrove: implication for the impact of restoration and afforestation. Glob Ecol Conserv 4:423-433

Lindh MV, Lefébure R, Degerman R, Lundin D, Andersson A, Pinhassi J (2015) Consequences of increased terrestrial dissolved organic matter and temperature on bacterioplankton community composition during a Baltic Sea mesocosm experiment. Ambio 44:402-412

Liu J, Peng M, Li Y (2012) Phylogenetic diversity of nitrogen-fixing bacteria and the nifH gene from mangrove rhizosphere soil. Can J Microbiol 58:531-539

Lu X, Sun S, Zhang YQ, Hollibaugh JT, Mou X (2015) Temporal and vertical distributions of bacterioplankton at the Gray's Reef National Marine Sanctuary. Appl Environ Microbiol 81:910-917

* Marie D, Partensky F, Jacquet S, Vaulot D (1997) Enumeration and cell cycle analysis of natural populations of marine picoplankton by flow cytometry using the nucleic acid stain SYBR green I. Appl Environ Microbiol 63: 186-193

* Martin BD, Witten D, Willis AD (2020) Modeling microbial abundances and dysbiosis with beta-binomial regression. Ann Appl Stat 14:94-115

* Monger BC, Landry MR (1993) Flow cytometric analysis of marine bacteria with Hoechst 33342. Appl Environ Microbiol 59:905-911

Moran MA (2015) The global ocean microbiome. Science 350:aac8455

Moriarty DJW, Pollard PC (1982) Diel variation of bacterial productivity in seagrass (Zostera capricorni) beds measured by rate of thymidine incorporation into DNA. Mar Biol 72:165-173

* Moriarty DJW, Boon PI, Hansen JA, Hunt WG and others (1985) Microbial biomass and productivity in seagrass beds. Geomicrobiol J 4:21-51

Needham DM, Fuhrman JA (2016) Pronounced daily succession of phytoplankton, archaea and bacteria following a spring bloom. Nat Microbiol 1:16005

Nelson CE, Alldredge AL, McCliment EA, Amaral-Zettler LA, Carlson CA (2011) Depleted dissolved organic carbon and distinct bacterial communities in the water column of a rapid-flushing coral reef ecosystem. ISME J 5: 1374-1387

Neubauer SC, Piehler MF, Smyth AR, Franklin RB (2019) Saltwater intrusion modifies microbial community structure and decreases denitrification in tidal freshwater marshes. Ecosystems 22:912-928

Oksanen J, Blanchet FG, Friendly M, Kindt R and others (2019) Vegan: community ecology package. R package version 25-4. https://CRAN.R-project.org/package=vegan

* Parada AE, Needham DM, Fuhrman JA (2016) Every base matters: assessing small subunit rRNA primers for marine microbiomes with mock communities, time series and global field samples. Environ Microbiol 18:1403-1414

* Park S, Jung YT, Kim S, Yoon JH (2016) Marinobacterium aestuariivivens sp. nov., isolated from a tidal flat. Int $\mathrm{J}$ Syst Evol Microbiol 66:1718-1723

Partensky F, Blanchot J, Vaulot D (1999) Differential distribution and ecology of Prochlorococcus and Synechococcus in oceanic waters: a review. Bulletin de l'Institut Océanographique 19:457-475

* Peduzzi P, Herndl GJ (1991) Decomposition and significance of sea-grass leaf litter (Cymodocea nodosa) for the microbial food web in coastal waters (Gulf of Trieste, Northern Adriatic Sea). Mar Ecol Prog Ser 71:163-174

Peterson CH (1991) Intertidal zonation of marine invertebrates in sand and mud. Am Sci 79:236-249

* Pohlner M, Dlugosch L, Wemheuer B, Mills H, Engelen B, Reese BK (2019) The majority of active Rhodobacteraceae in marine sediments belong to uncultured genera: a molecular approach to link their distribution to environmental conditions. Front Microbiol 10:659

*Polónia ARM, Cleary DFR, Freitas R, Coelho FJR da C, de Voogd NJ, Gomes NCM (2016) Comparison of archaeal and bacterial communities in two sponge species and seawater from an Indonesian coral reef environment. Mar Genomics 29:69-80

*Quast C, Pruesse E, Yilmaz P, Gerken J and others (2013) The SILVA ribosomal RNA gene database project: improved data processing and web-based tools. Nucleic Acids Res 41:D590-D596

Reef R, Feller IC, Lovelock CE (2010) Nutrition of mangroves. Tree Physiol 30:1148-1160

Ken H, Ma H, Li H, Huang L, Luo Y (2019) Acidimangrovimonas sediminis gen. nov., sp. nov., isolated from mangrove sediment and reclassification of Defluviimonas indica as Acidimangrovimonas indica comb. nov. and Defluviimonas pyrenivorans as Acidimangrovimonas pyrenivorans comb. nov. Int J Syst Evol Microbiol 69: 2445-2451

* Sánchez-Carrillo S, Sánchez-Andrés R, Alatorre LC, Angeler DG, Álvarez-Cobelas M, Arreola-Lizárraga JA (2009) Nutrient fluxes in a semi-arid microtidal mangrove wetland in the Gulf of California. Estuar Coast Shelf Sci 82: $654-662$

* Santoro AE, Casciotti KL, Francis CA (2010) Activity, abundance and diversity of nitrifying archaea and bacteria in the central California Current: nitrification in the central California Current. Environ Microbiol 12:1989-2006

* Sasi Jyothsna TS, Rahul K, Ramaprasad EVV, Sasikala C, Ramana CV (2013) Arcobacter anaerophilus sp. nov., isolated from an estuarine sediment and emended description of the genus Arcobacter. Int J Syst Evol Microbiol 63: 4619-4625

* Sun F, Zhang X, Zhang Q, Liu F, Zhang J, Gong J (2015) Seagrass (Zostera marina) colonization promotes the accumulation of diazotrophic bacteria and alters the relative abundances of specific bacterial lineages involved in benthic carbon and sulfur cycling. Appl Environ Microbiol 81:6901-6914

* Sutton DC, Besant PJ (1994) Ecology and characteristics of bdellovibrios from three tropical marine habitats. Mar Biol 119:313-320

* Sweet MJ, Croquer A, Bythell JC (2010) Temporal and spatial patterns in waterborne bacterial communities of an island reef system. Aquat Microb Ecol 61:1-11 
Toledo G, Bashan Y, Soeldner A (1995) Cyanobacteria and black mangroves in northwestern Mexico: colonization, and diurnal and seasonal nitrogen fixation on aerial roots. Can J Microbiol 41:999-1011

Ugarelli K, Chakrabarti S, Laas P, Stingl U (2017) The seagrass holobiont and its microbiome. Microorganisms 5:81

Ugarelli K, Laas P, Stingl U (2018) The microbial communities of leaves and roots associated with turtle grass (Thalassia testudinum) and manatee grass (Syringodium filliforme) are distinct from seawater and sediment communities, but are similar between species and sampling sites. Microorganisms 7:4

US Environmental Protection Agency (1983) Nitrogen, ammonia. Method 350.1 (colorimetric, automated, phenate). In: O'Dell JW (ed) Methods for chemical analysis of water and wastes. USEPA, Cincinnati, OH, p 350.1-1-350.1-14

Vaulot D, Marie D (1999) Diel variability of photosynthetic picoplankton in the equatorial Pacific. J Geophys Res 104:3297-3310

Wang Y, Sheng HF, He Y, Wu JY, Jiang YX, Tam NFY, Zhou
HW (2012) Comparison of the levels of bacterial diversity in freshwater, intertidal wetland, and marine sediments by using millions of illumina tags. Appl Environ Microbiol 78:8264-8271

Weber L, Apprill A (2020) Diel, daily, and spatial variation of coral reef seawater microbial communities. PLOS ONE 15:e0229442

Weber L, Gonzalez-Díaz P, Armenteros M, Apprill A (2019) The coral ecosphere: a unique coral reef habitat that fosters coral-microbial interactions. Limnol Oceanogr 9999: $1-16$

Wickham H (2016) Ggplot2: elegant graphics for data analysis. Springer Verlag, New York, NY

* Yu Z, Cao Y, Zhou G, Yin J, Qiu J (2018) Mangrovicoccus ximenensis gen. nov., sp. nov., isolated from mangrove forest sediment. Int J Syst Evol Microbiol 68:2172-2177

* Yun J, Deng Y, Zhang H (2017) Anthropogenic protection alters the microbiome in intertidal mangrove wetlands in Hainan Island. Appl Microbiol Biotechnol 101: 6241-6252 


\section{Appendix.}

Table A1. Pairwise Wilcoxon Rank Sum test for difference in Bray-Curtis dissimilarity values between sites. BenjaminiHochberg adjusted p-values are reported in the table; significance below the 0.05 cutoff indicated in bold

\begin{tabular}{|c|c|c|c|c|c|c|c|}
\hline Sites & $\begin{array}{l}\text { Fish Bay } \\
\text { Mangrove }\end{array}$ & $\begin{array}{c}\text { Lameshur } \\
\text { Mangrove }^{\mathrm{a}}\end{array}$ & $\begin{array}{l}\text { Fish Bay } \\
\text { Seagrass }\end{array}$ & $\begin{array}{c}\text { Lameshur } \\
\text { Seagrass }\end{array}$ & $\begin{array}{l}\text { Cocoloba } \\
\text { Reef }\end{array}$ & $\begin{array}{l}\text { Ditliff } \\
\text { Reef }\end{array}$ & $\begin{array}{c}\text { Yawzi } \\
\text { Reef }\end{array}$ \\
\hline Lameshur Mangrove & 0.9805 & - & - & - & - & - & - \\
\hline Fish Bay Seagrass & $8.60 \times 10^{-12}$ & $1.90 \times 10^{-12}$ & - & - & - & - & - \\
\hline Lameshur Seagrass & $3.20 \times 10^{-10}$ & $4.80 \times 10^{-9}$ & $4.90 \times 10^{-6}$ & - & - & - & - \\
\hline Cocoloba Reef & $6.70 \times 10^{-8}$ & $6.60 \times 10^{-7}$ & $2.70 \times 10^{-7}$ & 0.0626 & - & - & - \\
\hline Ditliff Reef & 0.0149 & 0.0134 & $1.00 \times 10^{-12}$ & $2.20 \times 10^{-8}$ & $6.40 \times 10^{-5}$ & - & - \\
\hline Yawzi Reef & $3.50 \times 10^{-6}$ & $1.90 \times 10^{-5}$ & $6.70 \times 10^{-8}$ & 0.0024 & 0.1819 & 0.0068 & - \\
\hline Tektite Reef & $7.80 \times 10^{-10}$ & $1.60 \times 10^{-8}$ & $2.80 \times 10^{-7}$ & 0.3706 & 0.2842 & $1.20 \times 10^{-6}$ & 0.0141 \\
\hline
\end{tabular}
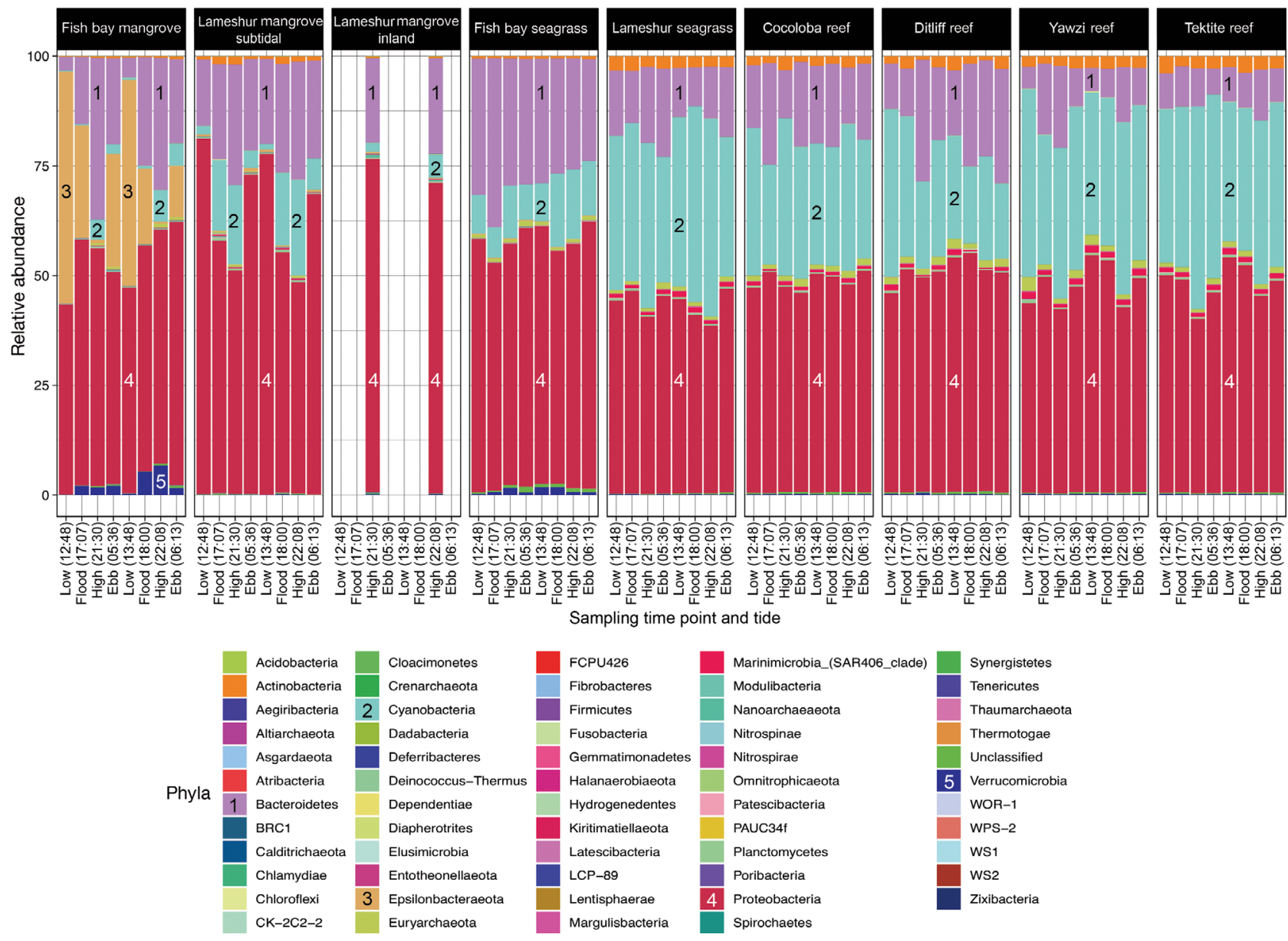

Fig. A1. Bar chart of relative abundance of amplicon sequence variants (ASVs) classified to the phylum level. Each site is represented by an individual chart. Bars are organized by sampling time point and tidal level on the $x$-axis. Colored bars each indicate a different phylum, with the dominant phyla numbered as followed: $1=$ Bacteroidetes, $2=$ Cyanobacteria, $3=$ Epsilon bacteraeota, $4=$ Proteobacteria, $5=$ Verrumicrobia

Editorial responsibility: Maiko Kagami, Yokohama, Japan
Submitted: February 25, 2020; Accepted: August 4, 2020

Proofs received from author(s): September 29, 2020 